\title{
Webtoon Short Story in English Online Class: Students' Perception
}

\author{
Sri Yuliani ${ }^{1 *}$ and Rezky Purnama Sari $\mathrm{M}^{2}$
}

\author{
${ }^{1}$ Universitas Islam Riau 1 \\ ${ }^{2}$ Universitas Islam Riau 2 \\ ${ }^{*}$ Corresponding author. Email: sriyuliani@edu.uir.ac.id
}

\begin{abstract}
The enforcement of online learning system has led new coercion of circumstances in education. No preparation in such condition got the teachers shocked, thus might had sudden actions to prepare their online class by preparing varieties of media. Webtoon short story was one of the alternative media used by teachers during covid-19. This paper discusses the findings of a study carried out to investigate the students' perception on webtoon short story in English classroom. The focus of this article was on students' point of view, students' manners and the students' thought in applying webtoon short story in English class. The sample was taken from three Senior High School in Pekanbaru at the grade eleventh. Questionnaire and interview were used to get the data. The findings of the study obtained from the quantitative showed that the statistical result indicated students' perception and interest on webtoon short story were positive and significantly shown in high level while in qualitative approaches showed that webtoon short stories used in English class was interesting, motivating and enjoying.
\end{abstract}

Keywords: English class, perception, teaching media, Webtoon short story

\section{INTRODUCTION}

The internet has brought changes to students, both through their life and their activities. The rapid progress in internet usage for students is an alternative source of learning to get more information. The use of the internet gives students opportunities to googling suitable learning sources like an e-book or other media that support their learning freely without paying much money and getting information for their studies. Many applications support students in online learning, like online and offline dictionaries, online vocabularies, online English games, online English quiz, online chat rooms for users all over the world, online text in reading text, online media applications, and others.

The Internet is a technology that provides the capability of broadcasting that is carried out once and spread throughout the world, a mechanism for disseminating information, and a medium that collaborates a place for individual interaction with computers without experiencing geographical location disturbances (Leiner, 1997). The internet is growing rapidly in Indonesia by the year the 2020s. The Indonesian Internet Service Providers Association (APJII) reported the results of a survey in 2020, Indonesian population was using the internet close to 197 million from the total number of Indonesian population that increased 8,9 percent from last year usage (Bayu, 2020), while the users of mobile phone in Indonesia reached 67 percent or 177.9 million people (Sidik, 2018). It means that most Indonesians are starting to apply digital activities (Gilakjani and Sabouri, 2016), furthermore, Indonesian internet users range between $16-24$ years old watched television more than 3 hours, listened to music more than 1 hour, and played games more than 1 hour (Jayani, 2020).

In addition, Indonesian government issued prevention Covid-19, an online learning system should be applied and reported that the massive sudden swift to online learning systems by using the internet brought students exposed to various learning applications in digital platforms to learn English easily that can be accessed anywhere and anytime (Putri \& Sari, 2020; Mandasari, 2020; Mandasari and Wahyudin, 2021). Lecturing was carried out by using many digital conference media like Zoom, Google Meet, Microsoft Teams, Cisco WebEx, Join Me, etc that were on the internet. Students searched e-books, e-learning materials, and e-modules and also additional media like audios or videos of lecturing, and also the assignments, tasks, assessments were implemented by using a computerbased system (Khalil et al, 2020). This was the enforcement of the online classroom system that had been held in Indonesia since last year until now due to covid-19. 
Some research has shown that the implementation of online learning during the Covid-19 has caused a positive impact on the learning process while others have less impact. An online learning system was reported better compared to a traditional system (Basilaia \& Kvavadze, 2020; Means et al., 2009). Online learning systems had high interaction to gather learning sources as well as had high opportunity to get experience in digital learning programs practices (Simamora, 2020; Firman \& Rahayu, 2020). In addition, the research found positive contributions toward online learning has been done by Schaer, Roizard, Christmann \& Lemaitres (2006) revealed that online learning demonstrated that this new teaching system did not decrease the time of teaching but motivated active learning, moreover, more practicing using technology for upgrading the students' skill. Another positive impact on the online learning system is increased enthusiasm for teachers and students and also increased the students' skills in technology (Khasanah, Pramudibyanto, \& Widuroyekti, 2020). The "2013 Survey of Online Learning," that has been conducted by Babson Survey Research Group, found that the increasing number of higher education students registered at one online course was above 7.1 million (Babson Study, 2014), it means that the number of enrolment students increased reaching almost 411,000 students during one the year 2013-2014 (Babson, 2014). However, in order side, some research found a negative impact of online learning that Esra Meşe and Çiğdem Sevilen (2021) found that students believed that online education got a negative impact on their motivation due to lack of social interaction, a mismatch between expectations and content, organizational problems and the organization of learning environments.

Some relevant research findings (Bakia, 2012; Powell et al., 2015; Alabbasi, 2017; Huang et al. 2020), there are two important components in online learning; namely content and instructions. Firstly, the content in online learning greatly influences the students' learning outcome. The content in online learning system for students should be varied and in interactive from animation, simulation, video, and audio. The content consists of the flexible source of learning to measure students' comprehension. The content also helps students in adapting the environment and students' needs, so, they are ready to get more sources to continue their learning. Secondly, the instructions are given by using internet that it provides the students with chat and comment room, so the students get response the assignment lively. Chatting and commenting room are conducting individually to the teachers, so the progress of students achieved is monitored secretly. The rules of communicating either between teachers to students and students to students are set before the online class begins. The instructions are also provided to group by teachers at the same time by using video conference Zoom, Google Meet, and WhatsApp video call. These instructions may held in many places which may be accessible by the teachers and the students.
Since the positive and negative research have been explored, the writer would like to expose the students' perception between offline and online learning system. Hass and Joseph (2018) examined students' perceptions on online to traditional system implemented in the business schools in Southwest USA at a liberal arts university. The research found that the students' perceptions comparison between online system with offline system, it seemed that they preferred traditional system.

Many research on WebToon short story had been done, Kiflaini (2021) did the research on "Students' Perception about Webtoon short story in Improving Students' Reading Comprehension Skills" revealed that webtoon is a media technology that can be used by students in reading skill. The research focused on WebToon short story toward students' reading skill and it showed that WebToon short story assisted students in comprehending reading skill. Other research Wike Idola Erya and Reza Pustika (2021), WebToon was media that given the students more interested in reading skill and they got motivation in improving their reading comprehension skills. Tifani, Regina \& Wardah (2020) found that WebToon short story was useful to help students in increasing students' courage in speaking skills by using storytelling technique, thus, the writer recommends WebToon short story in English speaking class.

Webtoon has shown many benefit in online learning system, an excellent online system, proven increasing students' excitement and comfortably searched (Jati, 2017). Webtoon short story also has shown advantages to increase the students' passion dealing with technology matters (Affeldt Meinhart, Meinhart \& Eilks, 2018). Some previous research project also conducted, they revealed that the users of Webtoon service were satisfied if they got their favorite information, thus the users felt satisfy in getting fun and scientific idea (Kim, Lee, Kwon \& Gim, 2016). It means that WebToon learning media has been used by WebToon readers for the purpose of getting interesting topics in term of learning sources.

Since the emergence of situation in Covid-19, the online media varieties should be measured and valued, thus based on the analysis of the above relevant research finding, most of the studies were on the range of achieving English competency while the tendency of students were interested in online, digital systems of learning is going to be measured, so the researchers would like find out the students' perception toward WebToon short story as one of the online teaching media in English class. is a fourth level heading. You can replicate it where suitable.

\section{METHOD}

Qualitative design was used in this research that the purpose was to find out students' perception on Webtoon in English online learning. This research took place for six weeks in three 
Senior high schools in Pekanbaru last semester on odd Semester 2020/2021. The WebToon short stories were used in online system. The link used was https://www.webtoons.com/en/genre that consisted 10 genres like action, romance, fantasy, drama, comedy, thriller, slice of life, supernatural, sci-fi, horror and others. Participants involved in filling the questionnaire this study included forty two female and twelve male students from three senior high schools in Pekanbaru Riau and only eight students were chosen to be interviewed.

The selection of the students involved in this study was based on the recommendation from Diknas Propinsi Riau which categorized that these schools have implemented Webtoon in online English class got from some interviews and chat. The participants were assigned numbers instead of their names. The data collection for this research was collected through six week meeting observations from the teachers and the end of sixth week, the researchers distributed questionnaires and conducted interview that the students were chosen randomly.

Online public opinion survey and online interview had been implemented during collection data through online system. Online opinion survey was redesigned from past studies done by Manowong (2016). The online public opinion survey consisted of 15 closed-ended questions with a four-Likert scale; namely strongly agree, agree, neutral, and disagree was given to fifty four students. The purpose of using this online opinion survey was to find out the students' opinion towards the use of online Webtoon short story in English classroom by providing three aspects of online system; they were Webtoon Short Story as an aspect of educational media, Webtoon Short Story as technical aspects, and Webtoon Short Story as ease of use aspects, meanwhile, interview was conducted to 8 students in order to find out in-depth explanation and description on the use of Webtoon short stories in English online learning in the aspects of interest, aspects of benefits, and the aspect of efficiency.

The analysis data started with collecting the score accumulated from the questionnaires with the range scale from each items that has been answered by students was measurably figured to discover the level of every statement and afterward interpreted descriptively. The interview data was interpreted and broke down which were indentified to the use of webtoon short stories in online English classroom.

\section{RESULTS AND DISCUSSION}

The main focus of this research was to find out the students' perception on the Webtoon short story in online English learning system. The result and the discussion will be elaborated with the findings of questionnaire and interview. The result data of online questionnaire was taken from 54 students from three senior high schools in Pekanbaru Riau while interview data was taken from 8 students chosen purposively. The interview was carried out using a purposive technique of 8 informants conducted through online interviews (WhatsApp). The interviewees who were successfully interviewed online by using initials name; namely, AA, JZ, MR, RE, SF, W, YN, and YQ. Interviews with 8 students with initials carried out at Wednesday, August 12, 2020. All data from this study were described based on the focus of the research questions as follows:

Table 1. Students' Perceptions on the Use of Webtoon Short Story as an Aspect of Educational Media

\begin{tabular}{|c|c|c|c|c|c|}
\hline \multirow[t]{2}{*}{ No } & \multirow[t]{2}{*}{ Questions } & \multicolumn{4}{|c|}{ Options } \\
\hline & & $\begin{array}{l}\text { Strongly } \\
\text { Agree }\end{array}$ & Agree & Neutral & Disagree \\
\hline 1 & $\begin{array}{l}\text { I think the use of Webtoon short story increases the } \\
\text { effectiveness of finding English learning materials }\end{array}$ & $22.22 \%$ & $68.52 \%$ & $3.70 \%$ & - \\
\hline 2 & $\begin{array}{l}\text { I think Webtoon short story helps me acquiring } \\
\text { new English vocabularies }\end{array}$ & $27.78 \%$ & $68.52 \%$ & $3.70 \%$ & - \\
\hline 3 & $\begin{array}{l}\text { I think the use of Webtoon short story helps me } \\
\text { practicing my English language skills }\end{array}$ & $40.74 \%$ & $53.70 \%$ & $5.56 \%$ & - \\
\hline 4 & $\begin{array}{l}\text { I think the use of Webtoon short story makes my } \\
\text { reading experience more interesting }\end{array}$ & $25.93 \%$ & $70.37 \%$ & $3.70 \%$ & - \\
\hline 5 & $\begin{array}{l}\text { I think the use of Webtoon short story helps me a } \\
\text { lot in practicing the dialogical verbal language } \\
\text { which helps me in speaking skill }\end{array}$ & $37.04 \%$ & $62.96 \%$ & - & - \\
\hline & Average Percentage & $30.74 \%$ & $64.81 \%$ & $3.33 \%$ & \\
\hline
\end{tabular}

Table 1 above, it can be seen that the Students' Perceptions on the Use of Webtoon Short Story as an Aspect of Educational Media shows that the average percentage for respondents chose Strongly Agree as amount as $30.74 \%$, Agree as amount as $64.81 \%$, and neutral $3.33 \%$ means that the students' perception of Webtoon short story in the aspect of educational media agreed that Webtoon short story provided them with source of learning materials were effectively to be found. The students also thought that Webtoon short story was easy to get new vocabularies enrichment, thus it helped students to practice English by using new vocabularies in improving their English skills either in reading, writing, or speaking, while the students who were not 
chosen either strongly agree or agree as amount as $3.33 \%$ showed the minimal average percentage to decide the options. So, it can be concluded that the high gap between agree and neutral of webtoon short story was that that students give positive response to Webtoon short story in the aspect of educational media.

The result showed that Webtoon short story as an educational media in the learning process that developed students' creativities and improved language skill steadily and in addition Webtoon short story as learning media also built an information technology competency framework in online learning system as supported by the previous research done by (Maryani, 2020); (Pratiwi \& Sudibyo, 2018); (Chinedu, Olabiyi \& Kamin, 2021); (Phan, Ngo, \& Phan, 2020).

Table 2. Students' Perceptions on the Use of Webtoon Short Story as Technical Aspects

\begin{tabular}{|c|c|c|c|c|c|}
\hline \multirow[t]{2}{*}{ No } & \multirow[t]{2}{*}{ Questions } & \multicolumn{4}{|c|}{ Options } \\
\hline & & $\begin{array}{l}\text { Strongly } \\
\text { Agree }\end{array}$ & Agree & Neutral & Disagree \\
\hline 1 & $\begin{array}{l}\text { I think Webtoon short story presenting the easiest } \\
\text { way for the readers to understand the story }\end{array}$ & $29.63 \%$ & $66.67 \%$ & $3,70 \%$ & - \\
\hline 2 & $\begin{array}{l}\text { I think Webtoon short story provides } \\
\text { attractiveness pictures to be read by the readers }\end{array}$ & $24.07 \%$ & $75.93 \%$ & - & - \\
\hline 3 & $\begin{array}{l}\text { I think Webtoon short story contains strong visual } \\
\text { images that help me to have clear vision in reading } \\
\text { the stories }\end{array}$ & $33.33 \%$ & $66.67 \%$ & - & - \\
\hline 4 & $\begin{array}{l}\text { I think Webtoon short story presents the } \\
\text { suitability of size of the images, written texts and the } \\
\text { balance of the layout in online comics }\end{array}$ & $27.78 \%$ & $68.52 \%$ & $3.70 \%$ & - \\
\hline 5 & $\begin{array}{l}\text { I think Webtoon short story has attractive } \\
\text { appearance, bright full colors, and many character } \\
\text { images }\end{array}$ & $20.37 \%$ & $74.07 \%$ & $5.56 \%$ & - \\
\hline & Average Percentage & $27.04 \%$ & $70.37 \%$ & $3.59 \%$ & \\
\hline
\end{tabular}

Table 2 shows that many students agreed that Webtoon short story as technical aspects increased their eager to read the stories. The visual images, pictures, size, layout, colors, attractive appearance, and imaginative characters engage them in interesting reading experience. The average percentage showed that mostly students agree with the percentage score $70.3 \%$ of the questionnaire calculation. Then $27.04 \%$, students strongly agree with the items stated above and the neutral as $3.59 \%$ showed the students just chose undecided to the items of the questionnaire. In line with the finding above, the relevant research found that the notion of Webtoon short story which had a representation of pictures to make it simpler for students to understand the examples of the material presented done the research by Danaswari (2013) and Webtoon short story also presented appealing pictures and straightforward comprehend storylines that made students more keen on learning (Evelyn et al., 2015). In addition, Webton short story creates an excellent atmosphere and an active students' responses in the classroom thus enjoy and have fun in accessing webtoon short story (Ai Setialis, Ansas, Diah Wulansari Hudaya \& Vegayanto Abdurrakhman Alfikri, 2017). Hence, comics truly help teachers in instructing and make it simpler for students to comprehend the subject. The outcomes showed that the use of Webtoon short story met technical aspects, in particular appealing appearance, clear textual styles, pictures and stories that have a suitability, adequate format, and the use of layout appropriately. The findings of this research in line with the assessment of the engaging quality of comics is impacted by a few components, like: eye catching appearance, the plot is rational and straightforward (Park et al., 2016).

Table 3. Students' Perceptions on the Use of Webtoon Short Story as Ease of Use Aspects

\begin{tabular}{|c|c|c|c|c|c|}
\hline \multirow[t]{2}{*}{ No } & \multirow[t]{2}{*}{ Questions } & \multicolumn{4}{|c|}{ Options } \\
\hline & & $\begin{array}{l}\text { Strongly } \\
\text { Agree }\end{array}$ & Agree & Neutral & Disagree \\
\hline 1 & $\begin{array}{l}\text { I think Webtoon short story is convenient and } \\
\text { easy to be accessed by the readers }\end{array}$ & $14.81 \%$ & $77.78 \%$ & $7.41 \%$ & - \\
\hline 2 & $\begin{array}{l}\text { I think Webtoon short story has clear instructions } \\
\text { for readers to choose their favorite stories }\end{array}$ & $18.52 \%$ & $74.07 \%$ & $7.41 \%$ & - \\
\hline 3 & $\begin{array}{l}\text { I think Webtoon short story use language that is } \\
\text { easy to understand }\end{array}$ & $27.78 \%$ & $27.22 \%$ & - & - \\
\hline 4 & $\begin{array}{l}\text { I think Webtoon short story provides many } \\
\text { episodes which are easy to follow the series }\end{array}$ & $25.93 \%$ & $74.07 \%$ & - & - \\
\hline
\end{tabular}




\begin{tabular}{|c|c|c|c|c|c|}
\hline & periodically & & & & \\
\hline 5 & $\begin{array}{l}\text { I think Webtoon short story is easily to be found } \\
\text { in the internet and available online }\end{array}$ & $37.04 \%$ & $62.96 \%$ & - & - \\
\hline & Average Percentage & $24.81 \%$ & $72.2 \%$ & $2.96 \%$ & \\
\hline
\end{tabular}

Table 3 shows that mostly students agree that Webtoon short story was easy to be accessed and convenient to use, got clear instructions, used simple language, had serial stories which were easy to browse, and provided online that can be viewed everywhere. The result of the questionnaire, students had positive perspective on Webtoon short story in the aspect ease of use with the score calculation as amount as $72.2 \%$ chose agree and $24.81 \%$ students chose strongly agree while only $2.96 \%$ students were in the neutral chosen which they were confuse to determine their decision in choosing the items. The result of the research above was supported by Sumanjaya and R. T. Padmaningrum (2018) found that Webtoon short story are digital online comic which was very easy to be accessed anywhere by using mobile phone or computer or laptop since most students equipped by smartphone or computer to study. J. H. Kim and J. Yu (2019) reveled that Webtoon short story was website cartoon in which the instructions to the users were easily to follow and used the easiest language for the readers to understand the story. Other finding from M.B. Kim, G. Gim and S.H. Lee, B.J. Kwon (2016) found that Webtoon enjoys benefits in learning, one of them is as great instructive media to further develop the students' keen in learning and its effortlessly got to anyplace, it got that the users of Webtoon values were fulfilled that they acquired the data they wanted, concerning the fascinating issues as well as significant issues, it was also supported by R. K. Jati (2017) revealed that Webtoon also can possibly build self-inspiration in confronting logical issue in light of the fact that Webtoon readers don't just get fascinating things, yet in addition learning material. Connecting to the interview result, the interview result will be describe below, eight students were giving their opinion about Webtoon short story in the aspects of interest, aspects of benefits, and the aspect of efficiency. The researchers conducted interview to obtain data from students. According to $\mathrm{W}$ says that in her opinion Webtoon short story is very fun because the story in this comic is very interesting and many stories she may choose to be her favorite one.

Moreover, AA says reading stories from Webtoon short story made her relaxed and she really enjoyed the series, it seemed that she was curious to find the next events. In addition $\mathrm{JZ}$ stated that he think it really supports the learning process because it looks fun and not boring. RE added that it was fun to use Webtoon Short Story because it has a lot of attractive pictures that can make her focused on the stories.

MR said that in his opinion, it was good to use Webtoon short story in the classroom, because from the stories and pictures presented, he can imagine the stories and can feel the atmosphere in the story and sometimes he cried if the story was sad drama, or he laughed or smile when the story was funny....so, webtoon short story enable him to build imaginations. In addition SF said that she enjoyed reading Powtoon and sometimes she lost her time controlled and she did not realize time run faster.

In addition YQ have positive perception toward Webtoon short story, she said that Webtoon has given her chances to get accessed with various type of genre ...it was efficient because she can read English reading text easily and together add her vocabularies collection, so she realized that Webtoon led her with simple English and she was easily understood the periodically stories...she said sometimes she was waiting the next episode curiously.

However, contrary to the other students, YN said she did not like to read the Webtoon series, she said it wasted her time and she felt guilty to her parents because she just spent her internet package to watch Webtoon but in one condition if the purpose for studying she felt fine. In this case, the researchers continuously interviewed $\mathrm{YN}$ to find more about her opinion and perception towards Webtoon short story, then the researchers got the source of her negative response on Webtoon short story. Her responses were online learning system created her boring in doing many assignments and task while all teachers assigned her and her friends with full load of tasks, she did not have real communication and she met her friends online. These situation turned her motivation down and felt reckless. The result of this negative response of online learning system was supported by Esra Meşe and Çiğdem Sevilen (2021) revealed that the social interaction, content knowledge in mismatch with the curriculum and syllabus, and also the environment setting were not at school but at home, these situation brought negative impact students' motivation.

The positive responses from the result of interview showed that the responses from students mostly giving positive perception on Webtoon short story. In the aspect of interest and motivation, benefit, and efficiency, the students' statements were positively proved that they have good impression. These findings was supported by Kiflaini (2021) found that Webtoon has given contribution to students to motivate students in learning language.

The research findings on students' interview was also in line with Oktaviani, Mandasari, \& Maharani (2020) found that Powtoon which was an online application that assisted students with working on their manners in learning environment, change their knowledge attitude from did not know to be adored. Other findings was from Pais, Nogués, and Muñoz (2017) uncovered that Powtoon showed positive benefits on the students' motivation, in addition their 
input in learning new substance and creating English language skills.

The result of the interview above also revealed that Webtoon short story given the students motivation, fun, felt enjoy, and also showed the efficiency of watching Webtoon. These result finding was in line with the research of (Affeldt, et.,al, 2018; Kim, et.,al 2016) that has shown Webtoon short story has given advantages to increase motivation of students and made the students enjoy reading the Webtoon short story.

\section{CONCLUSION}

Covid-19 has impacted the traditional learning system in face to face system swift to online system. This research addressed the students' perception on Webtoon short story in English online class. Six aspects of Webtoon short story to be evaluated towards student's perception that were taken from questionnaire and interview, thus the result of questionnaire showed that aspect of educational media on students' perception toward Webtoon short story, the average percentage $64.81 \%$ students Agree that Webtoon short story contributed them with education content in English in term of reading, speaking, and writing skills. The aspect of technical, the response of students' perception on Webtoon short story were positive shown by the average score $70.37 \%$ students agree that the flexibility, easy to access, the attractive images and pictures, colorful design and imaginary characters made students felt comfortable and secured in watching Webtoon short story. Finally, the result from the third aspect ease of use from questionnaire data showed that $72.2 \%$ students agreed that Webtoon short story helped students with the convenient and easily accessed for students to search the stories. Webtoon short story provided clear and easy instructions and language for students to goggle the series of which issued periodically, these helped students a lot in accomplishing their assignment and task.

The interview result that was taken from three aspects of interest, benefit, and efficiency showed that most students revealed positive responses toward Webtoon short story. The result of students' perception on Webtoon short story indicated that each aspect contributed good point and the students got motivated, enjoy, and relax when they read the Webtoon short stories, although some students revealed that they lost time and did not realize the situation. However, the interview result also revealed that the situation of online learning had brought some frustrated feeling because the monotonous situation gave them uneasy and boring.

Apart from frustrated issue, the interview result also informed us that a some difficulties occurred, for example lack of communication among friends and teachers, lack of friendships' environment has caused troubles for students to do conversation which done in online learning system.

Based on the interview result indicated that it was necessary to grant students with comfortable and suitable application and media which given students more chances and opportunity for them to have their own way of learning style without any prerequisite and specific condition which lead tense and constraint. Realizing this situation, the researchers suggest to other researchers to find out the needs of students in online learning media to provide real support on the students' way of learning.

This research has limitation on small sample size and non-random selection. Small sample and the selection was chosen randomly to support the data, so it limited the generalization of exposing the maximize data in the result findings. Future researchers are suggested to use the fixed sample size or purposive selection techniques. Hopefully future research not only students' opinion to be explored but also the problems faced by teachers regarding online learning system. To sum up, the research was on the students' perception on Webtoon short story, analyzing the opinions of each aspects in the questionnaire and interview items with less the implementation of media applied might produce more critical results.

\section{ACKNOWLEDGMENTS}

This work is supported by the Universitas Islam Riau Grants. The interviews cited in this article are part of the data collected for the project. I would like to express great thanks to all those from my teamwork for their assistance in data collection.

\section{REFERENCES}

[1] Alabbasi, D. Exploring graduate students' perspectives towards using gamification techniques in online learning. Turkish Online Journal of Distance Education, 18(3), 2017,180 196.

[2] B. Kim, S.-H. Lee, B.-J. Kwon, and G. Gim. A Study of the Effects of Webtoon Contents and Cooperative Characteristics on Open Collaboration Platform Usage. Int. J. Softw. Eng. its Appl., vol. 10, no. 9, 2016 (51-64). doi: 10.14257/ijseia.2016.10.9.06.

[3] Affeldt, D. Meinhart, and I. Eilks. (2018). The Use of Comics in Experimental Instructions in a Non-formal Chemistry Learning Context. Int. J. Educ. Math. Sci. Technol., vol. 6, no. 1. 2018(93-104). doi: 10.18404/ijemst.380620.

[4] Babson Study: Over 7.1 Million Higher Ed Students Learning Online. (n.d.). Retrieved November 23, 2020, from http://www.babson.edu/newsevents/babsonnews/pages/140115-babsonsurvey-study-of-online-learning.aspx.

[5] Bakia, M., Shear, L., Toyama, Y., \& Lasseter, A. Understanding the implications of online learning for educational productivity. U.S. Department of Education, Office of Educational Technology, 2012. https://tech.ed.gov/files/2013/10/implicationsonli ne-learning.pd. 
[6] Basilaia, G., \& Kvavadze, D. Transition to online education in schools during a SARS-CoV-2 coronavirus (Covid-19) pandemic in Georgia. Pedagogical Research, 5(4), 2020 (1-9).

[7] Bayu, D. J. Alasan Utama Orang Indonesia Gunakan Internet untuk Bermedia Sosial. Retrieved from https://databoks.katadata.co.id/datapublish/2020 111/13/Alasan Utama Orang Indonesia Gunakan Internet untuk Bermedia Sosial $\mid$ Databoks (katadata.co.id)

[8] Britt, R. (2006). Online education: A survey of faculty and students. Radiologic Technology, 77(3), 2006 (183- 190).

[9] C. C. Chinedu, O. S. Olabiyi, Y. Bin Kamin. (2021). Strategies for improving higher order thinking skills in teaching. ISSN: 2089-9823 J Edu \& Learn, Vol. 15, No. 1, February 2021: $119-126$.

[10] C. Phan, T. T. Ngo, T. M. Phan. (2020). Assessment of information technology use competence for teachers: identifying and applying the information technology competence framework in online teaching, Journal Technical Education and Training, vol. 12, no. 1, pp. 149162, 2020. doi: 10.30880/jtet.2020.12.01.016.

[11] D. B. Harmoko and M. S. Sumbawati. (2017) "Mobile Webtoon Development in Game Programming Courses at Universitas Negeri Surabaya (in Bahasa)," IT-EDU, vol. 2, no. 1, pp. 102-109.

[12] Erya, W. I. \& Pustika, R. (2021). Students' Perception Towards the Use of Webtoon to Improve Reading Comprehension Skill. Journal of English Language Teaching and Learning, 2(1), 51-56.

[13] F. Affeldt, D. Meinhart, and I. Eilks. (2018). The Use of Comics in Experimental Instructions in a Non-formal Chemistry Learning Context. Int. J. Educ. Math. Sci. Technol., vol. 6, no. 1, pp. 93104, 2018, doi: 10.18404/ijemst.380620.

[14] Firman, F., \& Rahayu, S. (2020). Pembelajaran online di tengah pandemi covid-19. Indonesian Journal of Educational Science (IJES), 2(2), 8189.

[15] Gilakjani, P., Sabouri, A., \& Banou, N. (2016). How Can Students Improve Their Reading Comprehension Skill? Journal of Studies in Education, 6(2), 229. https://doi.org/10.5296/jse.v6i2.9201.

[16] Hass, A. and Joseph, M. (2018). Investigating different options in course delivery-traditional vs online: is there another option?. The International Journal of Information and Learning Technology, Vol. 35 No. 4, pp. 230239, available

at:

https://www.emerald.com/insight/content/ doi/10.1108/IJILT-09-2017-0096/full/html.
[17] Huang, R.H., Liu, D.J., Tlili, A., Yang, J.F., Wang, H.H., et al. (2020). Handbook on facilitating flexible learning during educational disruption: The Chinese experience in maintaining undisrupted learning in COVID-19 outbreak. Smart Learning Institute of Beijing Normal University.

[18] J. H. Kim and J. Yu. Platformizing Webtoons: The Impact on Creative and Digital Labor in South Korea. Soc. Media Soc., vol. 5, no. 4, 2019 (1-11). doi: 10.1177/2056305119880174.

[19] Jayani, D. H. (2020). Rata-rata Waktu yang Dihabiskan Pengguna Internet Umur 16-24 Tahun (2020). Retrieved from https://databoks.katadata.co.id/datapublish/2020/ 02/26/10-rata-rata-waktu-yang-dihabiskanpengguna-internet-umur-16-24-tahun.

[20] Kaur, G. Digital Life: Boon or bane in teaching sector on COVID-19. CLIO an Annual Interdisciplinary. Journal of History, 6(6), 2020 (416-427).

[21] Kiflaini. Students' Perception about Webtoon in Improving Students' Reading Comprehension Skills. Retrieved at $10^{\text {th }}$ June 2021 in Academia.edu.

https://www.academia.edu/45154066/Students_P erception_about Webtoon_in_Improving_Stude nts' Reading Compehension.

[22] Khasanah, D. R. A. U., Pramudibyanto, H., \& Widuroyekti, B. Pendidikan dalam Masa Pandemi Covid-19. Jurnal Sinestesia, 10(1), 2020 (41-48).

[23] Leiner, B. M. A brief history of internet. Studies in Health Technology and Informatics, 36, 1997 (121-132). https://doi.org/10.3233/978-1-60750880-9-121.

[24] M.-B. Kim, S.-H. Lee, B.-J. Kwon, and G. Gim. A Study of the Effects of Webtoon Contents and Cooperative Characteristics on Open Collaboration Platform Usage. Int. J. Softw. Eng. its Appl., vol. 10, no. 9, 2016 (51-64). doi: 10.14257/ijseia.2016.10.9.06.

[25] Maryani, Y. Pengembangan Komik sebagai Media Pembelajaran Teks Biografi Dalam Upaya Meningkatkan Minat Baca Pada Siswa Kelas X SMKN 3 Bandung. Wistara, III(1), 2020 (4549).

[26] Means, B., Toyama, Y., Murphy, R., Bakia, M. and Jones, K. Evaluation of Evidence-Based Practices in Online Learning: A Meta-Analysis and Review of Online Learning Studies. Department of Education, Office of Planning, Evaluation, and Policy Development, Washington, D.C, 2009.

[27] Meşe, E. \& Sevilen, Ç. Factors influencing EFL students' motivation in online learning: A qualitative case study. Journal of Educational Technology \& Online Learning, 4(1), 2021 (1122). 
[28] Park, Y., Yim, S., \& Jeong, H.-S. (2016). Imagining through webtoon: Webtoon-focused convergence education project in middle school. Cartoon and Animation Studies, 45, 2016 (451477).

https://doi.org/10.7230/koscas.2016.45.451.

[29] Pratiwi, D. K. P., \& Sudibyo, E. Keefektifan Penggunaan Media Pembelajaran Komik Pada Materi Gerak Untuk Meningkatkan Minat Baca Siswa SMP Kelas VIII. Pendidikan Sains, 6(2), 2018 (290-295).

[30] Powell, A., Roberts, V., \& Patrick, S. Using online learning for credit recovery: Getting back on track to graduation. International Association for K-12 Online Learning. (2015) https://aurorainstitute.org/resource/using-online-learning-forcreditrecovery-getting-back-on-track-tograduation/.

[31] R. K. Jati. The design of Webtoon comic media about historical lesson (IPS) of 5th grade elementary school in Jogja (in Bahasa). EProceeding of Art \& Design, vol. 4, no. 3, 2017 (685-694).

[32] Schaer. E, Roizard. C, Christmann. N, Lemaitre. A. Development and Utilization of an E-learning Course on Heat Exchangers at ENSIC. Education for Chemical Engineers, Vol 1, Issue 1, 2006 (82- 89).

[33] Setialis, A., Hudaya, D. and Ansas, V. The Implementation of LINE Webtoon Application in Promoting the EFL Teachers' Creativity - The Teachers' and Students' Perception. DOI: 10.5220/0007161100090013 In Proceedings of the Tenth Conference on Applied Linguistics and the Second English Language Teaching and Technology Conference in collaboration with the First International Conference on Language, Literature, Culture, and Education (CONAPLIN and ICOLLITE 2017) - Literacy, Culture, and Technology in Language Pedagogy and Use, 2017 (9-13) ISBN: 978-989-758-332-2

[34] Simamora, R.M. The Challenges of Online Learning during the COVID-19 Pandemic: An Essay Analysis of Performing Arts Education Students. Journal of Studies in Learning and Teaching, 1(2), 2020 (86-103).

[35] Tifani, Regina, Wardah.. Improving Students' Confidence in Speaking by Storytelling Technique Through Webtoon. JEEP Vol.1 No.1 2020 (19-28).

[36] U. Sumanjaya and R. T. Padmaningrum. (2018). Develompment of chemistry Webtoon for learning of macromolecule material (in Bahasa). J. Pembelajaran Kim., vol. 7, no. 5, 2018(210219).

[37] Zhong, R. (2020). The coronavirus exposes education's digital divide. Retrieved from The New

$$
\text { York }
$$

Times: https://www.nytimes.com/2021/05/20/technolog y/china-schools-coronavirus.html. 